\title{
Strategies for Sustainable Environmental Management of Construction Activities in Ghana
}

\author{
Simon Ofori Ametepey ${ }^{*}{ }^{\mathbb{D}}$, Samuel Ansah2 ${ }^{2}$, William Gyadu-Asiedu ${ }^{3}$ \\ ${ }^{1}$ Koforidua Technical University, Koforidua, Ghana \\ ${ }^{2}$ Building Technology Department, Cape Coast Technical University, Cape Coast, Ghana \\ ${ }^{3}$ Faculty of Built \& Natural Environment, Koforidua Technical University, Koforidua, Ghana \\ Email: *simon.ametepey@ktu.edu.gh
}

How to cite this paper: Ametepey, S.O., Ansah, S. and Gyadu-Asiedu, W. (2020) Strategies for Sustainable Environmental Management of Construction Activities in Ghana. Journal of Building Construction and Planning Research, 8, 180-192. https://doi.org/10.4236/jbcpr.2020.83011

Received: July 19, 2020

Accepted: September 19, 2020

Published: September 22, 2020

Copyright $\odot 2020$ by author(s) and Scientific Research Publishing Inc. This work is licensed under the Creative Commons Attribution International License (CC BY 4.0).

http://creativecommons.org/licenses/by/4.0/

\begin{abstract}
The Ghanaian construction industry continues to improve by the recent intensification of infrastructure development by government and the private sector. Nonetheless, this is happening with a strong focus on economic development to the detriment of the environment these activities affect. This paper focuses on identifying the strategies by which sustainable environmental management could be structured to mitigate the impact of construction activities in Ghana. A mixed-method research approach was adopted. Quantitative data were collected from 83 practitioners in the construction industry, while qualitative data were elicited from 18 Construction and Environmental Management practitioners. The mean scores indicated that all the 20 strategies for integrating environmental concerns into construction activities in Ghana were considered significant by the respondents. The empirical findings of the study indicate that for environmental concerns to be effectively integrated into construction activities in Ghana, a concerted effort will be required from the various actors within the construction industry. These include the role of clients in selecting environmentally conscious service providers, designers focusing on environmentally friendly construction materials and methods, reduce, recycling and reuse of waste materials, the commitment of government towards sustainable development, and well-structured educational campaigns to promote environmentally sustainable construction activities.
\end{abstract}

\section{Keywords}

Construction Industry, Environmental Management, Strategies, Sustainable Construction, Sustainable Development 


\section{Introduction}

Environmental deterioration has been one of the most discussed issues in recent times all over the world. In the construction industry, this situation is aggravated by the impact construction activities have on the environment [1] [2]. The acknowledgment of the interdependence of the construction sector and the environment has motivated the pursuit of a strategy to mitigate the impact of their interactions with one another and the overall impact on sustainable development (SD). SD has emerged as a possible alternative, taking a holistic approach to all developmental concerns. Sustainable development is not a new concept [3]. "The Brundtland Report, Our Common Future" has brought the concept to the international arena [4] and has been reaffirmed at subsequent global Earth Summits and several global efforts. SD is a dynamic, fluid concept that has evolved. Brundtland's most widely used definition is "development that meets current needs without compromising the ability of future generations to meet their own needs" [4]. The concept focuses on the incorporation of economic, environmental and social interests and the requirement that they are treated equally, both for intragenerational and intergenerational equity.

The creation, operation and disposal of construction activities form a significant source of impact on the natural world [5] [6]. It is a major consumer of non-renewable resources, produces substantial waste, pollutes air and water, and contributes to land dereliction [7]. As a result of these, sustainable construction has emerged as a guiding paradigm to create a new construction philosophy, with the primary goal of reducing the impact of construction activities on the environment [8]. Ghanaian construction industry's focus is primarily on economic growth, and improving people's quality of life, paying little attention to environmental concerns [9]. Kein et al. [10] described the building industry as uncareful and profit-driven, and members as environment-destroyers rather than protectors. The GDP released for the past ten (10) years by the Ghana Statistical Service, indicates that the construction industry has contributed enormously to the economy. Accordingly, the construction sector being a key contributor to the Ghanaian economy, illustrates its commitment to social and economic progress, while its detrimental relation to the climate is ignored. Unsustainable design, construction processes, as well as constant degradation of the environment for construction purposes characterize the construction industry in Ghana [11] [12].

It is significant to know, however, that little research has been conducted on sustainable construction in Ghana despite the worldwide consideration and applications of the concept. This explains the need to undertake this research and provide a holistic solution to the issues raised.

\section{Construction Activities and the Environment}

The construction sector comprises all who plan, construct, produce, build, improve or maintain the built environment and includes manufacturers and sup- 
pliers of construction materials, clients, contractors, consultants and facilities end-users [13]. Sustainable construction can thus be defined as a segment of sustainable development that includes issues such as bidding, site planning and organization, choice of materials, recycling and waste reduction [14].

Environmental protection is achieved through sustainable resource-efficient activities, protecting habitats, and maintaining the planet's carrying capacity. According to Ofori and Chan [15], customers and contractors can achieve sustainable construction by creating an environmental management team. Each development must include environmental protection in the project goal list, which traditionally contains only time, cost and quality considerations [16]. Bourdeau [17] believes that green development can be achieved by the cooperation of various construction industry stakeholders. Building customers and developers should encourage sustainable development, as they represent the building sector's demand. Developing environmentally conscious processes and having the ability to formulate, analyze and validate relevant environmental criteria to include these aspects are crucial to development [16] [18]. Besides, it is also essential for clients to set up an environmental policy for each project and to consider environmental track records when selecting consultants and contractors [16].

Building designers need to show environmental awareness in their design [15]. Bourdeau [17] suggests a more holistic design approach to understand the principles of sustainable building design and eco-labeling. Bourdeau [17] continues to say that design professionals should collaborate with suppliers to create new designs for material recycling. Building materials' environmental principles may be considered fundamental to design and life-cycle assessment models and use this to promote product development. Nonetheless, life cycle analysis in its present form is too complicated for efficient use, and input data is not appropriate for a complete assessment of building products as there are over 40,000 new products on the market in the pipeline [18]. Therefore, the life-cycle measurement of all goods on the market will take a long time. Nonetheless, it is vital for on-site construction methods to adopt environmentally-conscious techniques [15].

To achieve sustainable construction goals, it is also necessary to improve land use by regulating the conversion rate of agricultural land to support human settlement growth and urbanization [17] [19] [20]. At the same time, extending the life and reuse of existing buildings [21] [22] is essential, thus reducing the money required to construct new facilities. Current practices, however, also result in buildings built with very low life expectancy [21] [22] as the natural capital used is not considered to have any real value leading to misuse of such resources. The cost of rectifying environmental harm from resource production has not yet been adequately accepted as part of the cost to society of such resources. It is thus not included in the price charged by those purchasing the product.

The waste generated from construction activities is also a change goal, which is particularly essential for avoidable waste. Teo and Loosemore [23] claimed 
that wasteful activities are due to the convenient and cost-effective solution provided by landfill sites. They also said construction waste has residual value and can be avoided by introducing an effective waste management system. Spence and Mulligan [21] suggest that increased use of chemical, forestry, and demolition waste in a building would reduce the environmental impact of construction. It would also reduce the environmental impact of these mineral waste disposal. Significant research and development work have been devoted to minimizing construction waste and recycling strategies that put this back into the production process [24] [25] [26] [27]. John and Zordan [26], however, claimed that there are many barriers to recycling beyond technical difficulties, including cultural, geographic, legal, social, time and information barriers, all of which have hindered the full potential of promoting recycling in construction.

\section{Method}

A mixed-method research design was adopted for the study. It employed the use of quantitative and qualitative methods in the study for the identification of strategies for sustainable environmental management of construction activities in Ghana. Ritchie and Lewis [28] opined that quantitative and qualitative methods should not necessarily be seen as opposing approaches to research but instead as complementary strategies appropriate to different types of research questions.

Three categories of construction industry professionals were chosen for the quantitative study, which included Architects, Quantity Surveyors and Structural Engineers. The study design led to the selection of only professionals who are members of their specific professional bodies providing a research population of Architects, Quantity Surveyors, and Structural Engineers who are members of their respective professional bodies.

A stratified random sampling technique was utilized in the selection of participants. A total of 100 participants were initially sampled. This group comprised 58 Architects, 37 Quantity Surveyors, and 5 Structural Engineers. The first two groups (Architects and Quantity Surveyors) were slightly oversampled, primarily to ensure an adequate response rate for meaningful statistical analysis. The three groups of practitioners were employed as the strata in stratification to allow for proportional representation of practitioners across board. Simple random technique was then employed in selecting the practitioners within the various strata to avoid researcher biases in the selection. The minimum statistically acceptable sample size was determined by employing the Kish formula [29] to justify the responsive sample size of the survey.

Semi-structured interviews were conducted amongst eighteen (18) purposively selected experts in academia and industry for the qualitative study before the questionnaire survey. The interviews followed an attitudinal approach used to subjectively assess a person's or group's opinion on a particular attribute, element, factor or query. The process of collecting data involved two stages. The 
first stage was the search for literature on the environmental management of construction activities in other countries and interview of the experts. The aim of interviewing experts was to confirm a preliminary set of strategies for environmental management of construction activities gleaned from the literature and to determine from their experience other strategies for sustainable environmental management of construction activities in Ghana.

The second stage involved the development of an interview guide and questionnaire incorporating the strategies for sustainable environmental management of construction activities identified. Semi-structured interviews were conducted with eighteen (18) construction and environmental management experts. Respondents were briefed on the importance of the interview and its relevance to the investigation.

The questionnaire survey followed after the interview to test the strategies from literature and to also validate the findings of the interview. Primarily, the interview was also used as a precursor to the preparation of the questionnaire. The questionnaire was organized in the form of an agreement scale, and the overall scale recorded a slightly higher level of alpha reliability ( $\dot{\alpha}=0.85)$. Respondents were requested to tick a box according to their level of agreement of each of the strategies identified. The questionnaire consisted of two (2) sections: Part one and two. Part one sought to elicit data on the background of the participants, while part two assessed the strategies for integrating environmental concerns into construction activities in Ghana. The items on the questionnaire were scored on a 5-point Likert-type scale, ranging from strongly disagree (1) to strongly agree (5).

Of the 100 participants, 85 percent $(n=85)$ completed and returned the questionnaire. Two questionnaires, however, were rejected due to incomplete responses, which reduced the final sample to 83 . The questionnaires were personally delivered to the respondents by the researchers who also went back to collect them at appointed times.

The quantitative data were analyzed using the Statistical Package for Social Sciences (SPSS) version 16. Descriptive statistics such as percentages, frequencies, mean and standard deviation were used to summarize information from respondents. The interview data were analyzed using conceptual content analysis, which takes into account the appearance of a concept or the numbers of times (frequency) a particular concept appears in a text. Content analysis is a useful technique to help in understanding behavior, adopting a purely descriptive approach.

\section{Results}

\subsection{Background Information of Respondents}

The result of the background information of the respondents as presented in Table 1, shows that of the 83 respondents in the survey, 48 (57.8\%) were architects by profession, $30(36.2 \%)$ were quantity surveyors while $5(6.0 \%)$ were 
Table 1. Respondents' background information.

\begin{tabular}{|c|c|c|}
\hline Respondents' characteristics & Frequency $(\mathrm{n}=83)$ & Percentage (\%) \\
\hline \multicolumn{3}{|l|}{ Profession of Respondents } \\
\hline Architects & 48 & 57.80 \\
\hline Quantity Surveyor & 30 & 36.20 \\
\hline Structural Engineers & 5 & 6.00 \\
\hline \multicolumn{3}{|l|}{ Years of professional experience } \\
\hline $1-5 \mathrm{yrs}$ & 12 & 14.50 \\
\hline $6-10 \mathrm{yrs}$ & 39 & 47.00 \\
\hline $11-15$ yrs & 16 & 19.00 \\
\hline $16-20 \mathrm{yrs}$ & 7 & 8.20 \\
\hline Above 20 yrs & 9 & 11.3 \\
\hline \multicolumn{3}{|c|}{ Category of Respondents Organization } \\
\hline Contractor & 13 & 15.66 \\
\hline Consultant & 40 & 48.19 \\
\hline Client & 24 & 28.92 \\
\hline Others & 6 & 7.23 \\
\hline \multicolumn{3}{|l|}{ Educational Qualification } \\
\hline Diploma/HND & 3 & 3.61 \\
\hline B-Degree & 27 & 32.53 \\
\hline M-Degree & 19 & 22.89 \\
\hline Doctorate Degree & 8 & 9.64 \\
\hline Others & 26 & 31.33 \\
\hline
\end{tabular}

Structural engineers by profession. A large part (47\%) of the respondents' professional experience ranges between 6 - 10 years. It was also revealed that the entire respondents had some form of tertiary education with bachelor's degree being the highest (27\%). Of all the respondents, $15.67 \%$ work with contractors, $48.2 \%$ work with consultancy firms while $28.9 \%$ work with clients.

\subsection{Strategies for Integrating Environmental Concerns into Construction Activities in Ghana}

In this section of the questionnaire, the statements of the item pool sought the opinion of respondents on the logic of how environmental concerns can be integrated into construction activities. The evaluation of the various strategies was based on their mean scores. Comparison of the mean scores of all the strategies for environmental management showed no significant differences between the responses of the Architects, Structural engineers and the Quantity Surveyors at $5 \%$ significance level. Responses of both groups of respondents were then pooled together and presented in Table 2. Table 2 shows that mean scores of all the 20 strategies for integrating environmental concerns into construction activities 
Table 2. Mean Scores of strategies for integrating environmental management into construction activities.

\begin{tabular}{|c|c|c|c|}
\hline Environmental Management Strategy & $\begin{array}{l}\text { Mean } \\
\text { Score }\end{array}$ & $\begin{array}{l}\text { Standard } \\
\text { Deviation }\end{array}$ & Rank \\
\hline $\begin{array}{l}\text { 1) Clients should consider environmental track records when selecting } \\
\text { consultants and contractors }\end{array}$ & 3.97 & 0.216 & 1 st \\
\hline $\begin{array}{l}\text { 2) Consultants/designers should consider environmentally friendly } \\
\text { materials in their design }\end{array}$ & 3.95 & 0.143 & 2nd \\
\hline $\begin{array}{l}\text { 3) Waste generated from construction activities should be recycled into } \\
\text { other construction materials }\end{array}$ & 3.94 & 0.254 & $3 \mathrm{rd}$ \\
\hline $\begin{array}{l}\text { 4) Government should lead the campaign by ensuring all government } \\
\text { funded construction projects are environmentally friendly }\end{array}$ & 3.92 & 0.165 & 4 th \\
\hline $\begin{array}{l}\text { 5) Education and awareness raising are critical in promoting } \\
\text { environmentally sustainable construction }\end{array}$ & 3.91 & 0.432 & 5 th \\
\hline $\begin{array}{l}\text { 6) Clients should consider environmental protection as a project } \\
\text { objective in all projects in addition to the traditional objectives i.e. Cost, } \\
\text { time, quality etc. }\end{array}$ & 3.89 & 0.465 & 6th \\
\hline $\begin{array}{l}\text { 7) Contractors/builders should minimize waste during construction } \\
\text { works }\end{array}$ & 3.87 & 0.324 & 7th \\
\hline $\begin{array}{l}\text { 8) Government should come up with special legislations, codes or } \\
\text { standards relating to environmentally sustainable construction practices }\end{array}$ & 3.86 & 0.365 & 8th \\
\hline $\begin{array}{l}\text { 9) Manufacturers should create new designs which facilitate material } \\
\text { recycling }\end{array}$ & 3.85 & 0.536 & 9th \\
\hline $\begin{array}{l}\text { 10) All stakeholders in the construction industry should cooperate for } \\
\text { an environmentally sustainable construction industry }\end{array}$ & 3.83 & 0.477 & 10th \\
\hline 11) Clients should set up environmental policy for every project & 3.76 & 0.635 & 11 th \\
\hline $\begin{array}{l}\text { 12) Builders/Contractors should use environmentally friendly } \\
\text { construction methods on site }\end{array}$ & 3.75 & 0.543 & 12 th \\
\hline $\begin{array}{l}\text { 13) Suppliers must ensure materials supplied are produced through } \\
\text { environmentally friendly means }\end{array}$ & 3.73 & 0.645 & 13 th \\
\hline $\begin{array}{l}\text { 14) Stakeholders such as clients, contractors, consultants, government, } \\
\text { suppliers/manufacturers all have a key role to play collectively to } \\
\text { achieve sustainable construction }\end{array}$ & 3.72 & 0.485 & 14 th \\
\hline $\begin{array}{l}\text { 15) The final product of construction must be energy efficient and } \\
\text { environmentally friendly in its operation. }\end{array}$ & 3.66 & 0.691 & 15 th \\
\hline 16) Designers should show environmental consciousness in their design & 3.58 & 0.768 & 16th \\
\hline $\begin{array}{l}\text { 17) There is the need to improve land use by controlling the rate of } \\
\text { conversion of agric lands to support human settlements and } \\
\text { urbanization }\end{array}$ & 3.52 & 0.788 & 17 th \\
\hline $\begin{array}{l}\text { 18) Environmental impact assessment should be integrated into the } \\
\text { building permit process }\end{array}$ & 3.49 & 1.104 & 18th \\
\hline $\begin{array}{l}\text { 19) The national building regulations must be reviewed to include some } \\
\text { environmental regulations }\end{array}$ & 3.45 & 0.985 & 19th \\
\hline $\begin{array}{l}\text { 20) The environmental protection act should be reviewed to compel } \\
\text { Environmental impact assessment to be carried out for all construction } \\
\text { projects }\end{array}$ & 3.43 & 1.032 & 20th \\
\hline
\end{tabular}


evaluated by the three groups of respondents are greater than 3.0. A factor or strategy is deemed to be significant to the study if it has a mean value of 2.50 or more [30]. Thus, in the opinion of the respondents, all the twenty strategies are considered significant in integrating environmental concerns into construction activities in Ghana.

The results further show that "Clients should consider environmental track records when selecting consultants and contractors", "Consultants/designers should consider environmentally friendly materials in their design", "Waste generated from construction activities should be recycled into other construction materials", "Government should lead the campaign by ensuring all government funded construction projects are environmentally friendly", and "Education and awareness raising are critical in promoting environmentally sustainable construction" are the first five strategies for integrating environmental concerns into construction activities in Ghana according to the respondents as they recorded the highest mean scores.

Prior to the questionnaire survey, some experts in academia and industry were interviewed to seek their opinion about strategies for integrating environmental concerns into construction activities. Most of the experts interviewed stated that for environmental impacts of construction activities to be effectively managed, all the stakeholders within the construction industry have key roles to play. According to most of the experts, there will be a need for a concerted effort from all actors within the construction industry. They further espoused that the environmental roles of the various actors have to be properly delineated. From manufacturers and suppliers, clients, contractors, consultants, and government all have a responsibility to protect the environment. One key expert who is a consultant interviewed stated that:

"For environmental concerns to be effectively integrated into construction activities in Ghana, it will depend on a concerted effort from the various actors within the construction industry. Each actor has a key role to play to collectively achieve sustainability within the industry".

\section{Discussion}

The results of the study presented an indication of respondents' agreement to the strategies for integrating environmental concerns into construction activities in Ghana. A number of strategies to effectively manage the environmental impacts of construction activities were identified through literature of which respondents agreed to and also made their input.

Respondents strongly agreed that all players within the construction industry could achieve sustainable construction through a collective effort. Players such as clients, contractors, consultants, government, and suppliers/manufacturers all have a key role to play collectively to achieve sustainable construction. This is supported by Bourdeau [17] who opined that sustainable construction could also be achieved through the cooperation of various parties in the construction in- 
dustry. Ofori and Chan [15] also espoused this idea that sustainable construction can be accomplished by the clients and contractors forming a team to manage environmental issues. The experts interviewed also supported this idea and said that effective environmental management of construction activities can be achieved through the joint efforts of every person within the construction industry.

Respondents were asked to assess whether clients should consider environmental protection as a project objective in all projects in addition to the traditional objectives i.e. Cost, time, quality etc. Respondents strongly agreed to this strategy. While it is the desire of clients to meet the cost, time, quality targets of a project there is also the need to be committed to protecting the environment in order to have a balance. Ofori et al. [16] propounded that it is important that every construction project includes environmental protection to the list of project objectives, which traditionally include only time, cost and quality consideration.

The strategy of whether clients should set up environmental policy for each project was strongly agreed to by the respondents. It is very important for every client to formulate an environmental policy for every project. This policy will clearly articulate the measures that clients will initiate to ensure that activities of the project do not harm the environment. Ofori et al., [16] said that it is important for clients to set up an environmental policy for each project.

Respondents also strongly agreed to the strategy that clients should consider environmental track records when selecting consultants and contractors. Clients normally employ consultants, contractors, suppliers etc., so as part of selecting these people it is imperative for clients to consider their historical track records of environmental considerations. This idea is also supported by Ofori et al. [16]. Some of the "experts" interviewed also espoused this idea.

The next strategy, which was on whether contractors should use environmentally friendly construction methods on-site, was strongly agreed to by the respondents as well. Some of the "experts" interviewed suggested that before contractors commences work on-site, there is the need to assess all the activities and then adopt suitable environmentally friendly methods that will mitigate the environmental impacts in executing the activities. Ofori [15] recommended that it is important for contractors to adopt environmentally conscious techniques in construction methods on-site.

Furthermore, the respondents strongly agreed that contractors should adopt some measures to drastically minimize waste during construction works. Ineffective planning and methods lead to a lot of waste of materials on-site, which consequently demands more materials that come from the environment. Thus, there is the need for contractors to adopt proper planning and effective methods that will minimize material wastes as much as possible.

The strategy of whether designers should show environmental consciousness in their design was strongly agreed to by the respondents. Since the consultant 
designs and supervises the works, there is the need for consultants/designers to come up with environmentally friendly designs such as energy efficient designs etc. Ofori [15] advocated that it is important for building designers to show environmental consciousness in their design. Bourdeau [17] also suggested that a more integrated approach to design should be adopted to consider the fundamentals of sustainable building design and environmental labeling.

Respondents further agreed to the strategy that the Environmental Protection Law should be reviewed to compel environmental impact assessment to be carried out for every construction project. The Environmental Protection Agency Act (Act 460) exclusively specifies some particular construction projects that need to undergo environmental impact assessment before development. However, this strategy is of the view that since all construction activities have some form of impact on the environment, the Act 460 should be reviewed to compel environmental impact assessment to be carried out for all construction projects.

Besides, respondents strongly agreed to the idea that Government should come up with special legislations, codes or standards relating to environmentally sustainable construction practices. For sustainable construction practices to be effectively implemented in the construction industry in Ghana it is essential for government to come up with a specific legislation on sustainable construction that will oblige the construction industry players to adhere to it. Special sustainable construction code should also be developed to serve as a guide in the implementation of sustainable construction practices.

Respondents also agreed that suppliers must ensure materials supplied are produced through environmentally friendly means. It is necessary for manufacturers and suppliers to manufacture and supply environmentally friendly materials for all construction projects in Ghana. Also, it will be prudent to recycle construction wastes into other construction materials to reduce the pressure of obtaining raw materials from the environment. Bourdeau [17] suggests that building designers should work together with manufacturers to create new designs that facilitate material recycling.

\section{Conclusions}

The study reported that all the 20 strategies for integrating environmental concerns into construction activities in Ghana were considered significant by the respondents. "Clients should consider environmental track records when selecting consultants and contractors", "Designers should consider environmentally friendly materials in their design", and "Waste generated from construction activities should be recycled into other construction materials" were the first three strategies for integrating environmental concerns into construction activities in Ghana according to the respondents as they recorded the highest mean score. It is noted from the empirical findings of this study that for environmental concerns to be effectively integrated into construction activities in Ghana, it will depend on a concerted effort from the various actors within the construction in- 
dustry. Each actor has a key role to play to collectively achieve sustainability within the industry.

The findings of the study imply that all the strategies identified should be considered in the formulation of policies on environmental management of construction activities as they were all considered significant. The findings of the study will also inform another study to develop a framework to guide the integration of environmental concerns into construction activities by stakeholders within the construction industry.

\section{Conflicts of Interest}

The authors declare no conflicts of interest regarding the publication of this paper.

\section{References}

[1] Levin, H. (1997) Systematic Evaluation and Assessment of Building Environmental Performance (SEABEP). Proceedings of Second International Conference, Building and the Environment, Paris, 9-12 June 1997, 3-10.

[2] Shen L.Y. and Tam V.W.Y. (2002) Implementation of Environmental Management in the Hong Kong Construction Industry. International Journal of Project Management, 20, 535-543. https://doi.org/10.1016/S0263-7863(01)00054-0

[3] Adetunji, I., Price, A., Fleming, P. and Kemp, P. (2003) Sustainability and the UK Construction Industry: A Review. Engineering Sustainability, 156, 185-199. https://doi.org/10.1680/ensu.156.4.185.36962

[4] WCED (1987) Our Common Future: Report of the World Commission on Environment and Development. Oxford University Press, Oxford.

[5] Kibert, C.J., Sendzimir, J. and Guy, G.B. (2000) Defining an Ecology of Construction. Construction Ecology: Nature as the Basis for Green Buildings. Spon Press, New York, 7-28.

[6] Woolley, T. (2000) Green Building: Establishing Principles. In: Fox, W., Eds., Ethics and the Built Environment, Routledge, London, 44-56.

[7] Wallbaum, H. and Buerkin, C. (2003) Concepts and Instruments for a Sustainable Construction Sector. Industry and Environment: Sustainable Building and Construction. United Nations Environment Programme, 26, 53-57.

[8] Ofori, G. (2001) Challenges of Construction Industries in Developing Countries: Lessons from Various Countries. Proceedings of the 2 nd International Conference of the UB TG29 on Construction in Developing Countries: Challenges Facing the Construction Industry in Developing Countries, Gabarone, 15-17 November 2000, $1-13$.

[9] Ametepey, S.O. and Ansah, S.K. (2014) Impacts of Construction Activities on the Environment: The Case of Ghana. Journal of Construction Project Management and Innovation, 4, 934-948.

[10] Kein, A.T.T., Ofori, G. and Briffett, C. (1999) ISO 14000: Its Relevance to the Construction Industry of Singapore and Its Potential as the Next Industry Milestone. Construction Management and Economics, 17, 449-461. https://doi.org/10.1080/014461999371376

[11] Ametepey, S.O., Aigbavboa, C.O. and Ansah, S.K. (2015) Barriers to Successful Implementation of Sustainable Construction in the Ghanaian Construction Industry. 
Procedia Manufacturing, 3, 1682-1689.

https://doi.org/10.1016/j.promfg.2015.07.988

[12] Dadzie, J. and Djokoto S.D. (2013) Barriers to Sustainable Construction in the Ghanaian Construction Industry: Consultants' Perspectives Proceedings 5 th West Africa Built Environment Research (WABER) Conference, Accra, 12-14 August 2013, 223-234.

[13] CRISP (2000) Construction for Sustainable Development-Research and Innovation Needs. Strategy Panel, London.

[14] Langston, C.A. and Ding, G.K.C. (2001) Sustainable Practices in the Built Environment, 2nd Edition, Butterworth Heinemann, Oxford.

[15] Ofori, G. and Chan, P. (1998) Procurement Methods and Contractual Provisions for Sustainability in Construction. Proceedings of Construction and the Environment. CIB World Building Congress, Gävle, 7-12 June 1998, C296.

[16] Ofori, G., Briffett, C., Gang, G. and Ranasinghe, M. (2000) Impact of ISO 14000 on Construction Enterprises in Singapore. Construction Management and Economics, 18, 935-947. https://doi.org/10.1080/014461900446894

[17] Bourdeau, L. (1999) Sustainable Development and the Future of Construction: A Comparison of Visions from Various Countries. Building Research and Information, 27, 354-366. https://doi.org/10.1080/096132199369183

[18] Sterner, E. (2002) Green Procurement of Buildings: A Study of Swedish Clients' Considerations. Construction Management and Economics, 20, 21-30. https://doi.org/10.1080/01446190110093560

[19] Ofori, G. (1992) The Environment: The Fourth Construction Objective? Construction Management and Economic, 10, 369-395. https://doi.org/10.1080/01446199200000037

[20] Zhang, Z.H., Shen, L.Y., Love, P.E.D. and Treloar, G. (2000) A Framework for Implementing ISO 14000 in Construction. Environment Management and Health, 11, 139-149. https://doi.org/10.1108/09566160010321541

[21] Spence, R. and Mulligan, H. (1995) Sustainable Development and the Construction Industry. Habitat International, 19, 279-292.

https://doi.org/10.1016/0197-3975(94)00071-9

[22] Kohler, N. (1999) The Relevance of Green Building Challenge: An Observer's Perspective. Building Research and Information, 27, 309-320. https://doi.org/10.1080/096132199369426

[23] Teo, M.M.M. and Loosemore, M. (2001) A Theory of Waste Behaviour in the Construction Industry. Construction Management and Economics, 19, 741-751. https://doi.org/10.1080/01446190110067037

[24] Lowton, R.M. (1997) Construction and the Natural Environment. Butterworth Heinemann, Oxford.

[25] Poon, C.S., Yu, A.T.W. and Ng, L.H. (2001) On-Site Sorting of Construction and Demolition Waste in Hong Kong. Resources Conservation and Recycling, 32, 157-172. https://doi.org/10.1016/S0921-3449(01)00052-0

[26] John, V.M. and Zordan, S.E. (2001) Research and Development Methodology for Recycling Residues as Building Materials-A Proposal. Waste Management, 21, 213-219. https://doi.org/10.1016/S0956-053X(00)00092-1

[27] Klang, A., Vikman, P.A. and Brattebo, H. (2003) Sustainable Management of Demolition Waste-An Integrated Model for the Evaluation of Environmental, Economic and Social Aspects. Resources Conservation and Recycling, 38, 317-334. 
https://doi.org/10.1016/S0921-3449(02)00167-2

[28] Ritchie, J. and Lewis, J. (2003) Qualitative Research Practice: A Guide for Social Science Students and Researchers. SAGE Publications Ltd., London.

[29] Kish, L. (1965) Survey Sampling. John Wiley \& Sons Inc., New York.

[30] Field, A. (2005) Discovering Statistics Using SPSS. 2nd Edition, Sage Publications, London. 